\title{
THE EFFECTS OF FRESH AND THERMOXIDIZED PALM OIL DIETS ON SOME HAEMATOLOGICAL INDICES IN THE RAT
}

\author{
* O. E. MESEMBE, ${ }^{\#}$ I. IBANGA, and ${ }^{+}$E. E. OSIM
}

\author{
Departments of Anatomy, ${ }^{*}$ Haematology and ${ }^{+}$Physiology, College of Medical Sciences \\ University of Calabar, Calabar, Nigeria
}

Summary: The effects of fresh and thermoxidized palm oil diets on some haematalogical indices in the rat were investigated in albino rats (Wistar strain). The animals were divided into three groups namely, the first group fed on thermoxidized palm oil (TPO) diet, a second group fed on fresh palm oil (FPO) diet and a third fed on normal rat feed (control) only respectively for 14 weeks. Each of the palm oil diets contained 15\% (w/w) thermoxidized or fresh palm oil. The packed cell volume (PCV) of the TPO group $(44.87 \pm 0.8 \%)$ was significantly $(\mathrm{P}<0.001)$ lower than that of the FPO group $(52.50 \pm 0.4 \%)$ and control group $(54.75 \pm 1.3 \%)$. The haemoglobin $(\mathrm{Hb})$ concentration of the TPO group $(11.66 \pm 0.8 \mathrm{~g} / \mathrm{dl})$ was significantly $(\mathrm{P}<0.001)$ lower than that of control group $(13.14 \pm$ $0.4 \mathrm{~g} / \mathrm{dl})$ and the FPO group $(12.88 \pm 0.8 \mathrm{~g} / \mathrm{dl})$. The red cell count $(\mathrm{RBC})$ of the TPO group $(6.06 \mathrm{x}$ $10^{6} \pm 0.4 \times 10^{6}$ per $\mathrm{mm}^{3}$ of blood) was significantly $(\mathrm{P}<0.001)$ lower than that of control group $(7.28$ x $10^{6} \pm 0.4 \times 10^{6}$ per $\mathrm{mm}^{3}$ of blood) and the FPO group (7.19 x $10^{6} \pm 0.2 \times 10^{6}$ per $\mathrm{mm}^{3}$ of blood $)$. The white blood cell count (WBC) of the TPO group $\left(3.42 \times 10^{3} \pm 0.1 \times 10^{3}\right.$ per $\mathrm{mm}^{3}$ of blood) was significantly $(\mathrm{p}<0.001)$ higher than that of control group $\left(2.39 \times 10^{3} \pm 0.1 \times 10\right.$ per $\mathrm{mm}^{3}$ of blood) and FPO group (2.51 x $10^{3} \pm 0.1 \times 10^{3}$ per $\mathrm{mm}^{3}$ of blood). There were no significant differences between the heamatological indices of the fresh palm oil (FPO) and control groups. Our results suggest that chronic consumption of thermoxidized palm oil diet may result in anaemia and leucocytosis in the rat.

Key Words: Fresh palm oil; Thermoxidized palm oil; RBC; WBC; Hb; PCV.

\section{Introduction}

Palm oil, derived from the fruit of Elaesis guineensis is the most widely used cooking oil in Nigeria. It is consumed fresh or thermally oxidized. It is fresh when obtained from the pulp of the palm fruits by squeezing and boiling at low temperature to remove debris. It is thermally oxidized when the fresh form is subjected to several rounds of heating at high temperatures.

Fresh palm oil has low oxidation values (Rossel, 1983) and is relatively stable to oxidation (Gapor et al, 1989). Generally, oils are thermally oxidized to render them more palatable. However, the thermoxidation has a deteriorative effect on dietary oils (Perkins and van Akkerren, 1965; Peers and Swoboda, 1982; Isong, 1988). Also, following ingestion of thermally oxidized oil, there is a concomitant evolution of very cytotoxic and destructive by products (Plea, 1975; Frankel, 1980; Ziomski, 1982) which are injurious to cells tissues and organs (O’sara et al, 1969; Tappel 1973; Gabriel et al, 1979; Meredith, 1984).
Long term consumption of oxidized oils and fats has been reported to cause growth retardation, thrombosis, fatty livers, essential fatty acid deficiency, nucleic acid deficiency and micronutrient malnutrition leading to deactivation of key metabolic enzymes (Hill et al, 1982; Izaki et al, 1984; Golden and Ramdath, 1987; Isong et al, 1992; Osim et al, 1992). The free radicals that are generated may be involved in the etiology of diseases such as cancer, diabetes, arthritis, and cataract formation (Sun, 1990; Pryor, 1991; Lunec, 1992).

The haematological system is a major organ system. The vasculature in which blood flows present surface area of over $10000 \mathrm{~m}^{2}$, making this system interact extensively with other systems in the body (Mackie et al, 1999). And changes in haematological parameters may occur as a consequence of other systemic diseases (Mackie et al, 1999). There is therefore a possibility that thermoxidized palm oil diet will adversely affect the hematological system. This study examines this possibility. 


\section{Materials and Methods}

20 litres of fresh palm oil was purchased from Akim market in Calabar, Nigeria. The oil was divided into two equal portions. One portion was thermally oxidized as described by Isong (1988) and Osim et al (1992); whereas the other portion was used in its fresh form since these are the two common forms of palm oil used for cooking. The thermoxidied palm oil was obtained as follows:

Fresh palm oil was heated at $150^{\circ} \mathrm{C}$ in a stainless steel pot intermittently for five times with each lasting twenty minutes. At the end of each heating session, the oil was allowed to cool for five hours. Since the level of palm oil in most West African dishes is about 15\% (Umoh, 1972), fifteen grams of the cooled thermoxidized palm oil was mixed with eighty- five grams of rat feed and was designated test diet I. Fifteen grams of the fresh palm oil was mixed with eighty-five grams of rat feed and was designated as test diet II. The diets were stored in black containers at $4^{0} \mathrm{C}$ to prevent further oxidation of the oil component.

Twenty-four albino Wistar rats were bred in the animal house of the Department of Anatomy, University of Calabar, Calabar. The animals were divided into three groups of eight rats each. The rats were about the same age (56 - 60 days old) and

weighed between $50-55 \mathrm{~g}$ at the start of the experiments.

The rats in the first group were fed on thermoxidized palm oil diet (diet I). The second group was fed on fresh palm diet (diet II); while the third group served as the control group and was fed normal rat-feed. The feed was obtained from Livestock Feeds, Nigeria Limited, Lagos, Nigeria. Rats in the three groups were allowed the feed and water ad libitum for fourteen weeks.
At the end of the feeding protocol, the rats were anaesthetized with chloroform after over night fast. Blood was collected into heparinized screw cap bottles for determination of haemoglobin, red blood cell count, haematocrit and white blood cell count.

Haemacocrit (PCV) was estimated using microhaematocrit method according to Alexander and Griffiths (1993a); while haemoglobin $(\mathrm{Hb})$ concentration was determined using cyanomethaemoglobin method according to Alexander and Griffiths $\left(1993_{b}\right)$; whereas, the red blood cell count (RBC) and white blood cell (WBC) count were estimated by visual means using the new improved Neubauer counting chamber according to Dacie and Lewis (1991).

\section{Statistical Analysis}

Student's t - test and analysis of variance were used to analyze the data. Values of $\mathrm{P}<$ 0.001 were regarded as significant.

\section{Results}

The packed cell volume of thermoxidized palm oil group $(44.87 \pm 0.8 \%)$ was significantly $(\mathrm{P}<0.001)$ lower than that of the control (54. $75 \pm 1.3 \%)$ and fresh palm oil group (52.50 $\pm 0.4 \%)$. The packed cell volume of fresh palm oil group was not significantly different from the control group. (Fig.1).

The haemoglobin concentration of thermoxidized palm oil group (11.66 + $0.8 \mathrm{~g} / \mathrm{dl})$ was significantly $(\mathrm{P}<0.001)$ lower than that of control group $(13.14 \pm 0.4 \mathrm{~g} / \mathrm{dl})$ and fresh palm oil group (12.88 \pm $0.8 \mathrm{~g} / \mathrm{dl})$.There was no significant difference between that of the fresh palm oil group and that of control (Fig.2).

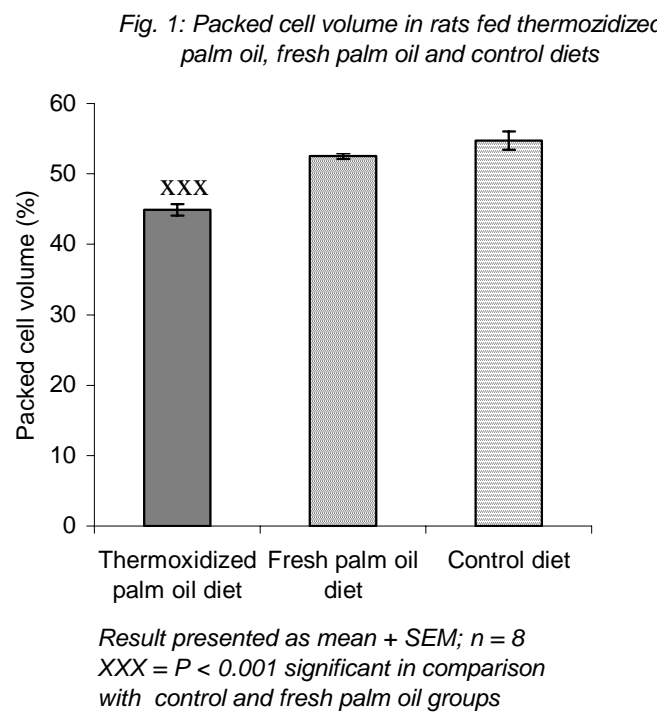


Fig. (2) Haemoglobin concentration in rats fed thermoxidized palm oil, fresh palm oil and control diets

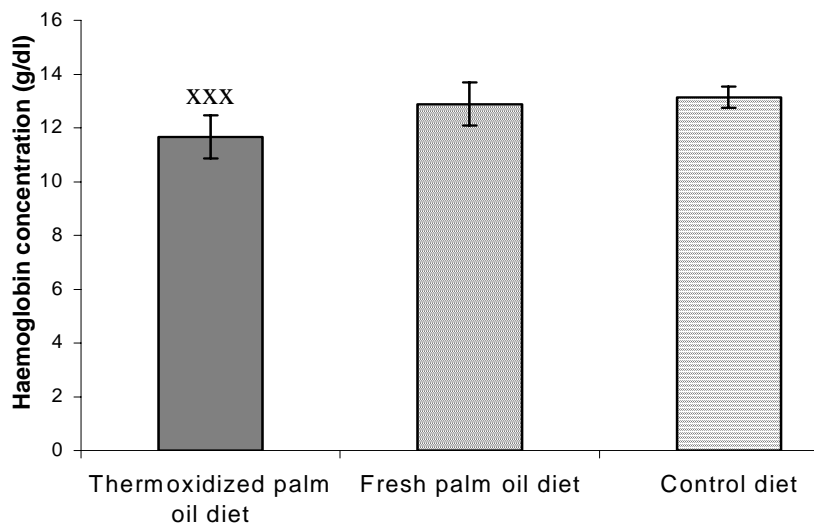

Result presented as mean + SEM; $\mathrm{n}=8$ $X X X=P<0.001$ significant in comparison with control and fresh palm

Fig. 3 Red blood cell count in rats fed thermoxidized palm oil, fresh palm oil and control diets

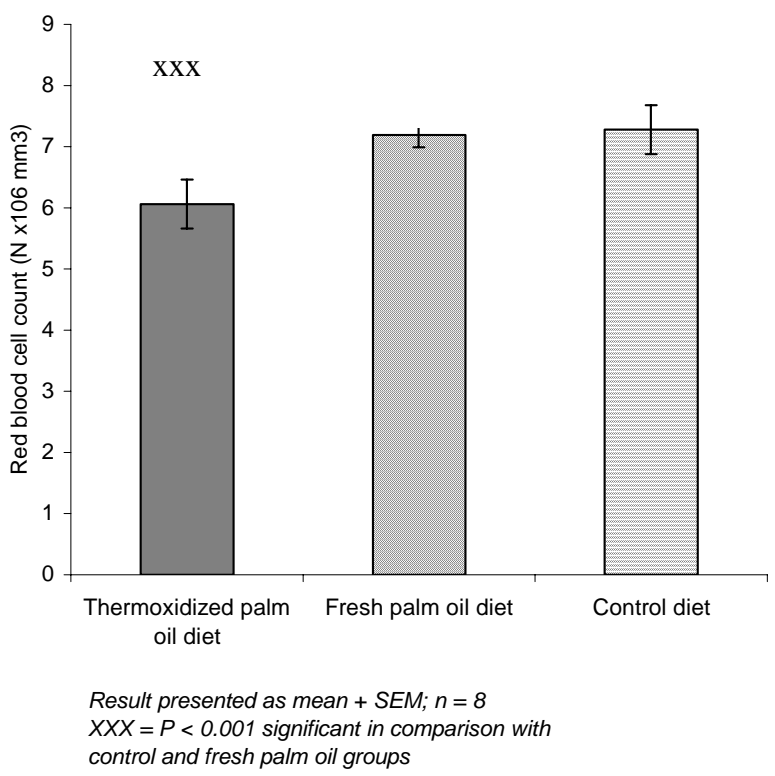

The red cell count of thermoxidized palm oil group $\left(6.06 \times 10^{6} \pm 0.4 \times 10^{6}\right.$ cells per $\mathrm{mm}^{3}$ of blood) was significantly $(\mathrm{P}<0.001)$ lower than that of control group $\left(7.28 \times 10^{6} \pm 0.4 \times 10^{6}\right.$ cells per $\mathrm{mm}^{3}$ of blood) and fresh palm oil group $(7.19 \mathrm{x}$ $10^{6} \pm 0.2 \times 10^{6}$ cells per $\mathrm{mm}^{3}$ of blood). There was no significant difference between that of the fresh oil group and that of control (Fig.3). The white blood cell count of thermoxidized palm oil group
(3.42 $\times 10^{3} \pm 0.1 \times 10^{3}$ cells per $\mathrm{mm}^{3}$ of blood) was significantly $(\mathrm{P}<0.001)$ higher than that of control $\left(2.39 \times 10^{3} \pm 0.1 \times 10^{3}\right.$ cells per $\mathrm{mm}^{3}$ of blood) and fresh palm oil group $\left(2.51 \times 10^{3} \pm 0.1 \times 10^{3}\right.$ cells per $\mathrm{mm}^{3}$ of blood). The difference between values of fresh palm oil group and control rats not significant (Fig.4). 


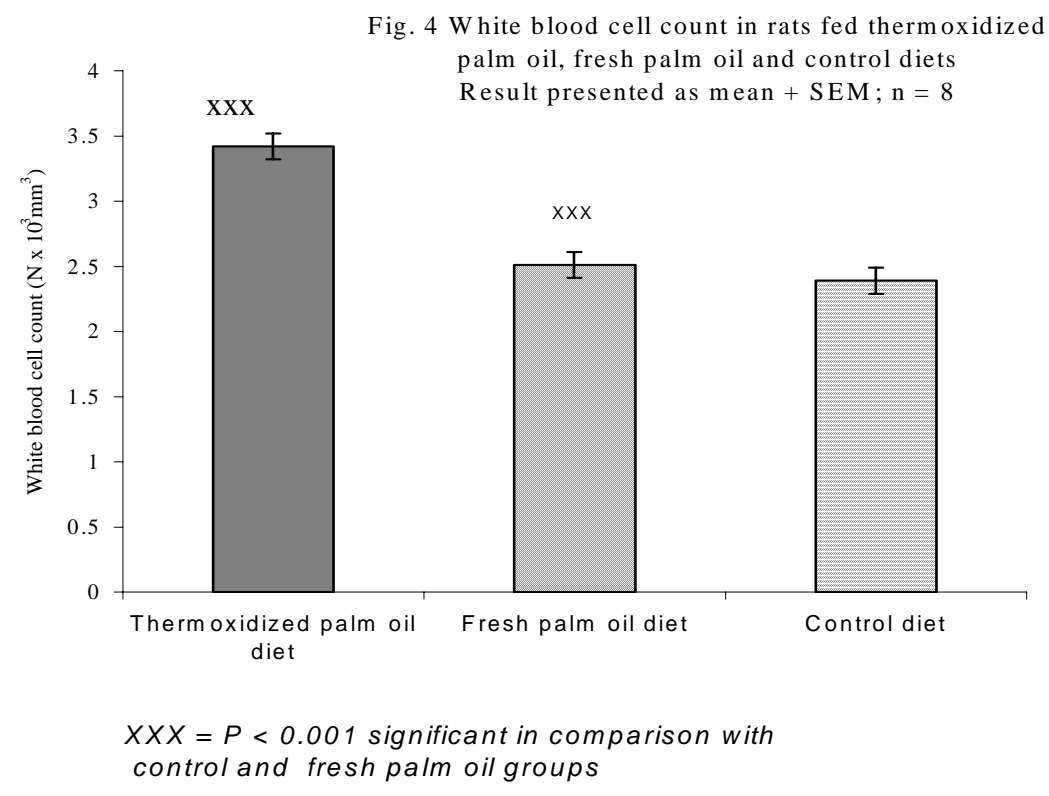

\section{Discussion}

In this study, the chronic consumption of thermoxidized palm oil diets by rats has been observed to cause alterations in haematocrit (PCV), haemoglomin ( $\mathrm{Hb})$, red blood cell (RBC) count and white blood cell (WBC) count.

These results showed that the RBC count was significantly lower in the rats fed thermoxidized palm oil diet when compared to the fresh palm oil and control groups. This decrease may be due to the suppressive effect of the hazardous constituents of thermally oxidized palm oil on the bone narrow. This is supported by experiments of O'sara et al (1979); Frankel, (1980) and Meredith (1984) who reported that the oxygen derived free radicals and dihydroxy esters contained in oxidized oils cause injury to cells, tissues and organs. These constituents may have suppressed the process of growth and differentiation in the marrow.

Failure of erythropoietin production may have also caused the decrease in RBC count in the group fed the test diet. The kidney is the main source of erythropoietin, which is produced by interstitial peritubular cells (Davidson et al, 1999). Osim et al (1994) demonstrated that thermoxidized palm oil diet causes tissue damage to the kidneyspecifically partial tubular atrophy. In fact, patients with renal dysfunction are anaemic due to failure of erythropoietin production (Eldestein et al, 1997).

The PCV otherwise known as haematocrit is a function of $\mathrm{RBC}$ concentration. It represents the percentage of RBC in blood (Kiraly, 1980). Therefore the decrease in PCV observed in this study is in agreement with the observed decrease in RBC counts.

The Hb concentration was significantly lower in the rats fed on thermoxidized palm oil diet when compared to rats fed on fresh palm oil and control diets. This decrease in $\mathrm{Hb}$ concentration may be a consequence of reduced uptake of iron by the damaged intestinal mucosa resulting in a reduced bioavailability of iron in the system. This is borne out by the work of Igiri et al, (1994), which showed that the intestinal mucosa of rats was severely damaged by chronic consumption of thermoxidized palm oil diet.

The decrease in Hb concentration may also be attributed to the decreased storage of iron in the liver as a result of damage to the liver. The liver stores iron as ferritin and haemosiderin (Finlayson et al (1999). In agreement, Osim et al (1994) have shown that congestion of hepatic sinusoids and degenerative changes in the hepatic lobules occurs in rats chronically fed thermally oxidized palm oil diet. The damage to the liver may have depleted the amount of iron stores and therefore resulted in lower haemoglobin concentration. Comparable low packed cell volumes, red blood cell count and haemoglobin concentration observed in rats fed thermoxidized palm oil diet indicate that the rats were anaemic.

The WBC counts was observed to increase in the rats fed on thermoxidized palm 
oil diet. This is in line with normal physiologic response following the perception of an insult by the body. Osim et al (1994) have demonstrated that consumption of thermoxidized palm oil diets caused liver damage. It is likely therefore that damage to the liver cells may have caused the insult that contributed to the observed increase in WBC count. In agreement, Finlayson et al (1999) have reported that leucocytosis may occur in hepatic damage.

Although there were no significant differences between the fresh palm oil and control groups, there was a tendency for haematological indices in rats fed on fresh palm oil diet to be different from rats fed on control. This may be so because other forms of oxidation e.g photolytic, enzymic, hydrolytic and chemolytic may be going on in the fresh palm oil (Artman, 1969; Frankel, 1980; Gurr and James, 1980; Lake and Waltherworth, 1980). There is therefore the need to protect fresh palm oil from various other sources of oxidation. Alternatively, fresh palm oil should be used as soon as it is prepared.

If the results are applicable in man, they suggest that there is reason for concern regarding adverse haematological consequence of chronic consumption of thermally oxidized palm oil diets. Chronic consumption of thermally oxidized palm oil diets may be dangerous to health since it may result in anaemia and leucocytosis. Therefore chronic consumption of this form of treated palm oil should be discouraged.

\section{References}

Alexander, R. R. and Griffiths, J. M. (1993a). Haematocrit in: Basic Biochemical methods, $2^{\text {nd }}$ ed., John Wiley and Sons Inc. New York, Pp 186-187.

Alexander, R. R. and Griffiths, J. M. (1993 $\left.{ }_{\mathrm{b}}\right)$. Haemoglobin determination by the cyanomethaemoglobin method. In: Basic Biochemical methods. $2^{\text {nd }}$ ed. John Wiley and Sons, Inc. New York. Pp188-189.

Artman, N. R. (1969). The chemical and biological properties of heated and oxidized fats Adv Lip Res 7:245-330.

Dacie, J. V., and Lewis, S. M. (1991). Practical haematology, Churchill Living Stone, Edinburgh, Pp41-57.

Davidson, A. M. Cumming, A. D., Swainson, C. P. and Turner, N. (1999). Diseases of the Kidney and Urinary systerm. In: Davidson's principles and practice of Medicine. Eds. Haslet C, Chilvers E. R,
Hunker J. A, Boon N. A. $18^{\text {th }}$ ed. Churchill Living Stone, Edinburgh Pp 417-470.

Edelstein, C. L., Ling. H. and Schrier, R. N, (1997). The nature of renal cell injury Kidney International 5: 1341-1351.

Finlayson, N. D. C., Hayes, P. C. and Simpson, K. J.(1999) Diseases of the liver and biliary system. in: Davidson's principles and practice of medicine. Eds. Haslet C, Chilvers E. R, Hunker J. A. A. Boon N. A., $18^{\text {th }}$ ed. Churchill Living Sone, Edinburgh. Pp 683-736.

Frankel, E. N. (1980). Lipid Oxidation Prog. Lipid Res. 19.1-22.

Gabriel, H. G., Alexander, J. C. and Valli, V. E. (1979). Biochemical and histological effects of feeding and thermally Oxidized rapeseed oil and Lard to rats. Can J. Comp. Med. 41:98-106.

Gapor, A. B., Ong, A. S. H., Kato, A. Watanabe, H., Kawada, T., (1989). Antioxidant activities of palm vitamin $\mathrm{E}$ with special reference to tocotrienol. Int J Oil Palm Res Dev. 1:63-67.

Golden, M. H. N., and Ramdath, D., (1987). Nutritional aspects of free radicals Free Radic Bio Med. 46:55-68.

Gurr, A. I. and James, A. T., (1980). Lipid Biochemistry, An introduction $3^{\text {rd }}$ ed. Chapman and Hall London. Pp 219-223.

Hill, E. G., Johnson, S. B., Lawson, L. D., Manfouz, M. M., Holman, R. T. (1982). Pertubation of the metabolism of essential fatty acids by dietary partially hydrogenated vegetable oil. Pro. Natl Acad. Sci. 79: 953 - 957.

Igiri, A. O., Ibegbu, A. O., Osim, E. E. (1994). The Morphological and histological changes in the small intestines induced by Chronic consumption of palm Journal for Applied Sciences.3and 4:144-153.

Isong, E. U. (1988). Biochemical and nutritional studies on rat of thermally oxidized palm oil (Elaesis guineensis). PhD. Thesis, University of Calabar, Nigeria.

Isong, E. U., Ifon, E. T., Eka, O. U. Essien, E. U. and Umoh, I. B. (1992). Effect of intermittently thermoxidized palm oil on normal and malnourished rats. Trop $J$. Appld Sci 2:118-121.

Izaki Y., Yoshikawa S and Uchiyama M., (1984). Effect of ingestion of thermally oxidized frying oil on peroxidative criteria in rats. Lipids 19(5):324-331.

Kiraly, D. A. (1980). Haematology problem. Am J. Med. Tech 80: 25-27. 
Lake, B., Walterworth, M., (1980). Foods and nutrition.Mills and Boon Ltd. London Pp10-20.

Lunec, H. (1992). Oxygen radicals, their measurement and role in major diseases. J I F C C 14(2): 58-63

Mackie, M. J., Ludlam, C. A. and Haynes, A. P. (1999). Diseases of the blood. In: Davidson's principle and practice of medicine. Eds Haslet C, Chilvers E. R, Hunker J. A.A, Boon NA, $18^{\text {th }}$ ed. Churchilll Livingstone, Edinburgh Pp 737-800

Meredith, S. (1984). Free radicals: Friend or foe? Medicine Digest 10 (4): 23-25

O'sara, R. W., Stewart, L, Brown, J. and Harph, W. C. (1969). Carcinogenicity of heated fats and fractions. J Natl Cancer Inst. 42: 275-278).

Osim, E. E., Owu D. U., Isong, E. U. and Umoh, I. B. (1994). Influence of Chronic consumption of thermoxidized and fresh palm oil diets on basal metabolic rate, body weight and Morphology of tissues in rats. Discov Innov. 6:389-396.

Osim, E. E., Owu, D. U., Isong, E. U. and Umoh, I. B. (1992). Influence of Chronic consumption of thermoxidized palm oil diet on platelet aggregation in the rat. Discov. Innov. 4:83087.

Peers, K. E. and Swoboda, P. A. T. (1982). Deterioration of sunflower seed oil under simulated frying conditions and during small scale frying of potato chips. J. Sci Food Agric. 33(4): 389 395.
Perkins, E. G., and vanAkkerren, L. A. (1965). Heated fats subjected to deep fat frying processes. J. Am. Oil Chem. Soc. 42: $161-166$.

Plea, R. M., (1975) Protein synthesis and absorption in rats fed with oxidized oil. Practitioner 224:306-421.

Pryor, W. A. (1991). The antioxidant nutrients. What we know, what to find out. Am . J Clin. Nut.r 53:3915-3935.

Rossell, J. B. (1983). Measurement of rancidity. In rancidily in foods. Ed, Allen JC, Hamilton R. J. Applied Sciences Publishers Ltd. England Pp.21 $-46$.

Sun, Y. (1990). Free radicals, antioxidant enzymes and carcinogens. Free Rad Biol Med 8:583-599.

Tappel, A. L. (1973). Lipid peroxidation damage to cell components. Fed. Proc. 32: 1870 - 1874.

Umoh, I. B. (1972). Changes in the nutritive values of some Nigerian diets after cooking by certain South eastern traditional methods. Ph.D. Thesis, University of Ibadan, Nigeria.

Ziombski, H. (1982). Chemical and nutritional changes in heated fats. III. Changes in nutritive value. Raezniki Panstwowego Zadkladu Itigiency, 33 (3): $162-170$.

Received: April 16, 2004

Accepted October 6, 2004 